\title{
Vowel Substitution of English Loanwords in Bemba
}

\author{
Kangwa Njenje Kennedy \\ Department of Linguistics, Kwame Nkrumah University - Zambia
}

\begin{abstract}
The present paper examines the adaptation of English loanwords in Bemba particularly substitution of vowels. According to Central Statistics Office of Zambia (2010), Bemba (coded by Guthrie (1948) as M42, is a widely used language of communication spoken by 33.5 percent of 13,092,666 people. It is a study of vowel substitution in Bemba which concludes that the recipient language reshapes English vowels to the closest available vowels in its phonemic inventory. The paper reveals that vowel substitution is a patterned and systematic phenomenon in Bemba loanword phonology. This research also concludes that, on the basis of available vowel substitution patterns, it is possible to make predictions regarding the upcoming English words where similar substitution of vowels may be observed.
\end{abstract}

Keywords: Adaptation, vowel substitution, diphthong, triphthong

\section{INTRODUCTION}

Vowel adaptation processes refer to how various vowels in loanwords are treated once they enter a recipient language (Boen, 2014). They are systematic sound changes that affect vowels. These vowel adaptation processes include vowel substitution and vowel preservation. Both vowel substitution and vowel preservation processes are discussed below.

\section{VoWEL SUBSTITUTION}

As can be seen from the two figures below, Bemba has five vowels while English has twelve. This implies that Bemba lacks some vowels and as a result the vowels missing in the Bemba phonemic inventory can be substituted with those present in English, which are perceived to be closer to the substituted vowels

$$
\text { i: }
$$

I

ә

$\mathrm{e}$

3: $\mathrm{u}:$

U i

$\mathrm{u}$

e
5:

$\mathrm{D}$

$æ$

$\Lambda$

$\mathrm{D}$

a:

Figure1. English vowel (Adapted from Roach 1983)

Figure2. Bemba vowel (Kangwa, 2007)

According to Hussain, Mahmood and Mahmood (2011), substitution is a general tendency to preserve sounds from deletion and it tries to reshape the word closer to the input form, but at the same time because some sound combinations are not allowed in the recipient language, they undergo certain adaptations. In substitution, an item is replaced to the phonetically-close phonemes in the recipient language (Hock, 1991).

Substitution is an unmarked process of sound change which is the characteristics of the majority of the languages of the world (Hussain, Mahmood and Mahmood, 2011). The examples of vowel substitution are discussed below. 


\subsection{Adaptation of the Schwa /a/}

This vowel is often referred to as schwa. "Schwa is, in terms of its articulation, neither high nor low, neither front nor back. It is a vowel produced with a neutral setting of the articulators and is in this respect a 'minimal' vowel, involving, as it does, no displacement of the articulators from the neutral position" (Giegerich 1992:68). This vowel does not occur in Bemba and is realised in Bemba as /a/, /e/, /i/, /o/ and /u/. This can be seen from the following examples

a) /o/ adapted as /a/

(1)

\begin{tabular}{|c|c|c|}
\hline English & & Bemba \\
\hline$/ \mathrm{b} \Lambda \mathrm{t} \partial(\mathrm{r}) /$ & butter & [baata] \\
\hline /'kæmərə/ & camera & [kaamela] \\
\hline /'kænsə(r)/ & cancer & kaansa \\
\hline / sentə(r) & centre & seenta \\
\hline / t $\mathrm{t} æ \mathrm{ptə(r)/}$ & chapter & caapita \\
\hline /'ko:rəs/ & chorus & koolashi \\
\hline / t $\int \mathrm{a}: \mathrm{d} 3 \partial(\mathrm{r})$ & charger & caaca \\
\hline / t $\mathrm{t} æ \mathrm{ptə(r)/}$ & chapter & capita \\
\hline /'kplərə/ & cholera & kolele \\
\hline / ko:rəs/ & chorus & kolashi \\
\hline
\end{tabular}

b) The schwa is also realised in Bemba as /i/ e.g.

(2)

English Bemba
「ærəti/Charity Chaliti
/'bætəri/ battery ibatili
c) /a/ adapted as /u/

Only one item was discovered:

(3)

$$
\begin{aligned}
& \text { English Bemba } \\
& \text { /,ka:bə'retə(r) 'carburettor' } \\
& \text { d) lo/ adapted as /e }
\end{aligned}
$$

(4)

$\begin{array}{ll}\text { English } & \text { Bemba } \\ \text { /'æksidənt/ 'accident' } & \text { akishitenti } \\ \text { /'erprəl/ 'April' } & \text { Epulelo } \\ \text { /'biznəs/ 'business' } & \text { biishineshi } \\ \text { /'kæmərə/ 'camera' } & \text { kaamela } \\ \text { /'ka:pəntə(r) 'carpenter' } & \text { kaapenta } \\ \text { /'kplərə/ 'cholera' } & \text { kolela } \\ \text { /'sinəmə/ 'cinema' } & \text { shinema } \\ \text { /'kpnvənt/ 'convent' } & \text { konifenti }\end{array}$




\section{/ kaŌnsələ(r) ‘councillor' kansela \\ /'disəntri/ 'dysentry' tisentili \\ e) /a/ adapted as /o/}

(5)

\begin{tabular}{|c|c|c|}
\hline English & & Bemba \\
\hline /,つ:tə`mætık/ & 'automatic' & otomatiki \\
\hline /.æpə'stplık/ & 'apostolic' & aposhito \\
\hline /'bi:kən/ & 'beacon' & bikoni \\
\hline /’biJəp/ & 'bishop' & bishopu \\
\hline /kə`ləひ̄niəl/ & 'colonial' & koloonyo \\
\hline /kə’ma:ndə(r) & 'commander' & komaanda \\
\hline /kə`ma:ndəひ/ & 'commando' & komaando \\
\hline /kə’miti/ & 'committee' & komiiti \\
\hline /kən`d $\Lambda$ ktə(r) & 'conductor' & kondaakita \\
\hline /'kærət/ & 'carrot' & kaaloti \\
\hline
\end{tabular}

In the examples above it is interesting to note the various substitutions of the English vowel /o/. Its realisation is complex because it is realised by all five Bemba vowels. The question here is why is this vowel realised by all the Bemba vowels? To answer this question, the phonetic qualities of this vowel and its position in the vowel chart need to be taken into consideration.

As mentioned above, this vowel is a neutral vowel; therefore its substitution by all the Bemba vowels may be explained with reference to phonetic approximation. The /a/ vowel occupies the most central position in the vowel chart. Because of its central position and its neutrality it can share phonetic characteristics with any peripheral vowel in Bemba

\subsection{Adaptation of the Central Vowel / $/$ /}

Giegerich (1992) describes this vowel as being unrounded and slightly more back than front. It is fully low in English dialects like RP. This vowel is replaced by /a/ in Bemba. Consider the following examples:

(6)

\begin{tabular}{|c|c|c|}
\hline & Bemba \\
\hline \multicolumn{2}{|l|}{ / k $\Lambda \mathrm{mp} ә n \mathrm{i} /$} & akaampani \\
\hline$/ \mathrm{k} 1 \Lambda \mathrm{t} \mathrm{f} /$ & 'clutch' & kalaaci \\
\hline$/ \mathrm{b} \Lambda \mathrm{s} /$ & 'bus' & baashi \\
\hline$/ \mathrm{b} \Lambda \mathrm{n} /$ & 'bun' & ibaanshi \\
\hline$/ 1 \Lambda \mathrm{nt} \int /$ & 'lunch' & laanci \\
\hline /m $\Lambda$ ndes/ & 'Monday' & Maande \\
\hline /ægrik $\Lambda \operatorname{lt} \int \partial(r)$ & 'agriculture' & kalakaca \\
\hline$/ \mathrm{d} \Lambda \mathrm{k} /$ & 'duck' & icitakishi \\
\hline$/ \Lambda \mathrm{p} ә(\mathrm{r}) /$ & 'upper' & aаpa \\
\hline /Am’brelə/ & 'umburella' & ambulela \\
\hline
\end{tabular}

The realisation of the English vowel $/ \Lambda /$ as $/ a /$ in the examples above seems to be due to phonetic approximation. Even though the English vowel is produced at a slightly higher level, both are low vowels. In the articulation of both vowels there is no rounding of lips. Therefore, the choice of the vowel /a/ as a substitute for the English vowel A seems to be determined by phonetic approximation. 


\subsection{The Back, Centralised High Vowel / $/ /$}

The English vowel $/ \mho /$ is also adapted in the language as $/ \mathrm{u} /$, with no exceptions. Once more, these vowels share all phonetic features, except that $/ \mho /$ is more centralised. This derivation is therefore plausible. The following examples were found in the data:

$\begin{array}{lll}\text { English } & & \text { Bemba } \\ \text { /bok/ } & \text { 'book' } & \text { buku } \\ \text { /bolit/ } & \text { 'bullet' } & \text { buuleti } \\ \text { bolfit/ } & \text { 'bull shit' } & \text { buulushiti } \\ \text { /'botfəri/ } & \text { 'butchery' } & \text { buucali } \\ \text { /bol/ } & \text { 'bull' } & \text { buulu } \\ \text { /kok/ } & \text { 'cook' } & \text { kuuki } \\ \text { /taorn/ } & \text { 'town' } & \text { tauni } \\ \text { / Jogə(r)/ } & \text { 'sugar' } & \text { shuka } \\ \text { /ful/ } & \text { 'full' } & \text { fuulu } \\ \text { /krok/ } & \text { 'crook' } & \text { kuluuku }\end{array}$

In all the examples above 'the English vowel/ / / is replaced by /u/. This substitution may be explained with reference to phonetic similarities between the two vowels. Both of these vowels are produced with the back part of the tongue and they also share the features [high] and [round], though to different degrees. It should be noted that when $/ \widetilde{J} /$ is integrated in Bemba, in most cases, it is lengthened.

\subsection{Adaptation of /u:/}

(8)

$\begin{array}{lll}\text { English } & & \text { Bemba } \\ \text { /'ba:Өru:m/ } & \text { 'bathroom' } & \text { bafwa } \\ \text { /'bedru:m/ } & \text { 'bedroom' } & \text { betiluumu } \\ \text { /bu:m/ } & \text { 'boom' } & \text { buumu } \\ \text { /bu:t/ } & \text { 'boot' } & \text { buuti } \\ \text { /bru:m/ } & \text { 'broom' } & \text { bulumu } \\ \text { /'su:tkers/ } & \text { 'suitcase' } & \text { sutikeshi } \\ \text { /kla:sru:m/ } & \text { 'classroom' } & \text { kalashiluumu } \\ \text { /kəm'pju:tə(r) } & \text { 'computer' } & \text { kompyuta } \\ \text { /'ku:lə(r) } & \text { 'cooler' } & \text { kuula } \\ \text { /'ku:pvn/ } & \text { 'coupon' } & \text { kuponi }\end{array}$

\subsection{The Front, Mid Vowel/E/}

In a majority of the loanwords, the English vowel /e/ is fully adapted in Bemba as /e/, with some cases of partial adaptation. Examples of full nativization of the vowel are given below:

(9)

$\begin{array}{llc}\text { English } & & \text { Bemba } \\ \text { /desk/ } & \text { 'desk' } & \text { [teshiki] } \\ \text { /hotelð/ } & \text { 'hotel' } & \text { otela } \\ \text { /`'dres/ } & \text { 'address' } & \text { ateleshi }\end{array}$




\begin{tabular}{lll}
\hline /sekfn/ & 'section' & sekisheni \\
/a:'men/ & 'amen' & aameni \\
/bed/ & 'bed' & beeti \\
/keIs/ & 'case' & keshi \\
/ssinəmə/ & 'cinema' & shinema \\
/t ek/ & 'cheque' & ceki \\
/si'ment/ & 'cement' & sementi
\end{tabular}

\section{6./e/ Adapted as /i/}

There was only one example in the data where /e/ is realised as /i/. This was found in the word 'engine' and its derivative 'engineer'. Examples:

$\begin{array}{llc}\text { English } & & \text { Bemba } \\ \text { /endzın/ } & \text { 'engine' } & \text { injini } \\ \text { /endzınəI/ } & \text { 'engineer' } & \text { injiniya }\end{array}$

\subsection{Adaptation of $/ \mathfrak{a} /$}

The front, open-mid English vowel /æ/ is invariably adapted in Bemba as /a/. This vowel, which can occur in both initial and medial positions within the English word, is rendered as /a/ in all such environments. Examples are as follows:

\begin{tabular}{|c|c|c|}
\hline $\begin{array}{l}\text { English } \\
\text { /spænə(r)/ }\end{array}$ & 'spanner' & $\begin{array}{l}\text { Bemba } \\
\text { shipaana }\end{array}$ \\
\hline /kæmp/ & 'camp' & kampu \\
\hline /'kæmərə/ & 'camera' & kaamela \\
\hline / $æ n t i /$ & 'shanty' & shanti \\
\hline /sæləri/ & ‘salary' & salale \\
\hline /sæk/ & 'sack' & isaaka \\
\hline / ţæptə(r)/ & 'chapter' & capita \\
\hline / t tææpl/ & 'chapel' & capeo \\
\hline /kæ`IIə(r) & 'cashier' & kashiya \\
\hline /'kærət/ & 'carrot' & kalooti \\
\hline
\end{tabular}

Because the vowel /æ/ does not occur in Bemba it is realised as /a/ in Bemba adoptives. This substitution is not accidental. The Bemba vowel /a/ is the one which is the closest to the English vowel /æ/. The Bemba vowel /a/ shares the feature [low] with that of the English vowel. Thus the substitution in this case is made on the basis of phonetic approximation.

\subsection{Adaptation of /3:/}

This English central vowel is realised in all its environments as /e/, without any exceptions. This can be seen in the following examples:

\begin{tabular}{|c|c|c|}
\hline English & & Bemba \\
\hline /sk3:t/ & 'skirt & [shikeeti] \\
\hline$/ \sqrt{3}: t /$ & 'shirt' & [ishaati] \\
\hline I'Z3:V/ & 'reserve' & [liseefu] \\
\hline
\end{tabular}




\begin{tabular}{lll}
\hline tz:m/ & 'term & [teemu] \\
/n3:s/ & 'nurse' & [naashi ] \\
/p3:m/ & 'perm' & [peemu] \\
/k3:tn/ & 'curtain' & [kaatani] \\
/k3: ju:/ & 'curfew' & [kefyu]
\end{tabular}

The examples given above show that the English vowel /3:/ is replaced by /e/ in Bemba loanwords. This substitution is due to the fact that the two sounds are phonetically close to each other. They are both mid-vowels and are produced without the lip-rounding.

\subsection{Adaptation of [s:]}

The English long, open mid, back vowel [o:] is realised in a majority of Bemba loanwords as [o:], with a few cases where it is rendered as [o]. The examples are as follows:

$\begin{array}{lll}\text { English } & & \text { Bemba } \\ \text { /ko:nə(r)/ } & \text { 'corner' } & \text { koona } \\ \text { /ko:pərəl/ } & \text { 'corporal' } & \text { kopolo } \\ \text { /ko:t/ } & \text { 'court' } & \text { kooti } \\ \text { /ko:s/ } & \text { 'course' } & \text { kooshi } \\ \text { /fo:k/ } & \text { 'fork' } & \text { foka } \\ \text { /fo:k/ } & \text { 'fooloko' } & \text { foloko } \\ \text { / fo:ti/ } & \text { 'forty' } & \text { foote } \\ \text { /ho:s/ } & \text { 'horse' } & \text { ioshi } \\ \text { /rn'fo:mə(r) } & \text { 'informer' } & \text { infoma } \\ \text { /'ki:bo:d/ } & \text { 'key board' } & \text { kibooti }\end{array}$

\subsection{Adaptation of $/ \mathbf{p} /$}

The back, low vowel $/ \mathrm{p} /$, in its fully adapted form, is realized in Bemba loanwords as $/ \mathrm{o} /$. This is the sound to which this vowel is closest in the language, both articulatorily and perceptually. Below are examples of its adaptation:

$\begin{array}{lll}\text { English } & & \text { Bemba } \\ \text { /bom/ } & \text { 'bomb' } & \text { ibomba } \\ \text { /'bonit/ } & \text { 'bonnet' } & \text { boneti } \\ \text { /bos/ } & \text { 'boss' } & \text { boshi } \\ \text { /'bntl/ } & \text { 'bottle' } & \text { ibotolo } \\ \text { /boks/ } & \text { 'box' } & \text { imbokoshi } \\ \text { /'kpmpaðnd/ } & \text { 'compound' } & \text { kompaundi } \\ \text { /'kpnsat/ } & \text { 'concert' } & \text { konsati } \\ \text { /'kpndwm/ } & \text { 'condom' } & \text { kondomu } \\ \text { /dzpb/ } & \text { 'Job' } & \text { Yobo } \\ \text { /lbk/ } & \text { 'lock' } & \text { loko }\end{array}$

2.11. Adaptation of /a:/

This open English vowel is realised in Bemba loanwords as /a/ in all its occurrences. Examples are as follows:

$\begin{array}{lll}\text { English } & & \text { Bemba } \\ \text { /da:ns/ } & \text { 'dance' } & \text { tanshi } \\ \text { /'æbətwa:(r)/ } & \text { 'abbatoir' } & \text { abatwa }\end{array}$




\begin{tabular}{lll}
\hline /o'la:m/ & 'alarm' & alamu \\
/a:'men/ & 'amen' & ameni \\
/a:nsə(r)/ & 'answer' & ansa \\
「a:mi/ & 'army' & ame \\
/bə’na:nə/ & 'banana' & banana \\
/ba:(r)/ & 'bar' & baa \\
/'ba:mən/ & 'barman' & baamani \\
/'ba:skit/ & 'basket' & bashiketi
\end{tabular}

\subsection{Adaptation of /I/}

The high, front English vowel is mainly realised in Bemba loanwords as /i/, with a few exceptions, as shown below:

\begin{tabular}{|c|c|c|}
\hline & Bemba \\
\hline \multirow{2}{*}{$/ \operatorname{tin} /$} & 'tin' & icintini \\
\hline & 'switch' & swici \\
\hline /'spirrt/ & 'spirit' & shipiliti \\
\hline /'bifəp/ & 'bishop' & bishopu \\
\hline /bridz/ & 'bridge' & bilici \\
\hline /brik/ & 'brick' & buliki \\
\hline / kæpıtl/ & 'capital' & kapito \\
\hline / $\mathrm{t} \int \mathrm{Imnni} /$ & 'chimney' & cimuni \\
\hline /sı’ga:(r)/ & 'cigar' & shikaa \\
\hline /disembə(r) & 'December' & Tisemba \\
\hline
\end{tabular}

There are some cases of partial nativization for this vowel in the data. These include the following examples:

\subsection{3. /I/ Adapted as [e]}

(17)

$\begin{array}{lc}\text { English } & \text { Bemba } \\ \text { /'kælındə(r) 'calendar' } & \text { kalenda } \\ \text { /,hælı'lu:jə/ 'halleluia' } & \text { aaleluya }\end{array}$

\subsection{Adaptation of /i/}

The high, front vowel /i/ is realised in Bemba as /i/, with no exceptions to this rule. This is shown in examples below:

$\begin{array}{lll}\text { English } & & \text { Bemba } \\ \text { /troli/ } & \text { 'trolly' } & \text { tololi } \\ \text { /sti: 'vi:/ } & \text { 'TV' } & \text { tiivi } \\ \text { /li:v/ } & \text { 'leave' } & \text { lifi } \\ \text { /æsid/ } & \text { 'acid' } & \text { ashiti } \\ \text { /ænti'nertl// } & \text { 'antenatal' } & \text { antinento } \\ \text { /ə'kwit/ } & \text { 'acquit' } & \text { akwiti }\end{array}$




\begin{tabular}{ccc}
\hline /'berkəri/ & 'bakery' & bekali \\
/'bætri/ & 'battery' & batili \\
/'bi:kən/ & 'beacon' & bikoni \\
/'biznəs/ & 'business' & bishineshi
\end{tabular}

\subsection{5. /i/ Adapted as /e/}

(19)

$\begin{array}{lll}\text { English } & \text { Bemba } \\ \text { / bizi/ } & \text { 'busy' } & \text { biise } \\ \text { ra:mi/ } & \text { 'army' } & \text { aame }\end{array}$

\section{Vowel Preservation}

It should be mentioned that not all English vowels are substituted when English words are borrowed into Bemba. In vowel preservation, some vowels within the loanwords do not change once they enter the recipient language (Boen, 2014). The following are the examples:

$\begin{array}{lllc}\text { English } & & \text { Bemba } & \text { Vowel Preserved } \\ \text { /fa:m/ } & \text { 'farm' } & \text { fwamu } & \mathrm{a} \\ \text { /'ba:.skit/ } & \text { 'baskit' } & \text { bashiketi } & \mathrm{a} \\ \text { /'pen } t \text {.s ə 1/ } & \text { 'pencil' } & \text { pensulo } & \mathrm{e} \\ \text { /'pen.i/ } & \text { 'penny' } & \text { peni } & \mathrm{e} \\ \text { /ru:m/ } & \text { 'room' } & \text { lumu } & \mathrm{u} \\ \text { /sku:1/ } & \text { 'school' } & \text { isukulu } & \mathrm{u} \\ \text { /ga'mora/ } & \text { 'Gomorrah' } & \text { komola } & \mathrm{o} \\ \text { /'florans/ } & \text { 'Florence' } & \text { fulolenshi } & \mathrm{o}\end{array}$

\section{General Remarks on The Substitution of Vowels in Bemba}

Bemba has adapted a large number of words from English. Some of the loanwords from this language contain vowels which are not found in the Bemba vowel inventory. As was shown in the previous discussion, these vowels are replaced by vowels that are found in the language. The replacement of these foreign vowels by native ones seems to be triggered by the native segment inventory constraint. Studies of other languages (cf.Kaye and Nykiel 1979; Holden 1976; Yavas 1982; Steinbergs 1984; Silverman 1992) have identified different constraints which operate in different languages. In Bemba, the native segment inventory constraint prevents the occurrence of any vowel which does not belong to the language sound inventory. Various Bemba vowels have therefore been used to replace the foreign vowels. These replacements do not, however, occur in an ad hoc manner. The substitution in these cases appears to be mainly due to phonetic approximation. In other words, foreign vowels are replaced by vowels which are closest to them in the recipient language. The substitution of the different simple vowels from English can be summarised as follows:

Table showing the summary of adaptation of English vowels into Bemba

\begin{tabular}{|c|c|}
\hline English Vowels & Realisation in Bemba \\
\hline$/ \mathrm{a} /$ & $\mathrm{a}, \mathrm{e}, \mathrm{i}, \mathrm{o}, \mathrm{u}$ \\
\hline$/ \Lambda /$ & $\mathrm{a}$ \\
\hline$/ \mathrm{\mho} /$ & $\mathrm{u}$ \\
\hline$/ \mathrm{u} / /$ & $\mathrm{u}$ \\
\hline$/ \mathrm{e} /$ & $\mathrm{e}, \mathrm{i}$ \\
\hline$/ \mathfrak{a} /$ & $\mathrm{a}$ \\
\hline$/ 3: /$ & $\mathrm{e}$ \\
\hline$/ \mathrm{o} /$ & $\mathrm{o}$ \\
\hline$/ \mathrm{p} /$ & $\mathrm{o}$ \\
\hline$/ \mathrm{a} / /$ & $\mathrm{a}$ \\
\hline$/ \mathrm{I} /$ & $\mathrm{i}, \mathrm{e}$ \\
\hline$/ \mathrm{i} /$ & $\mathrm{i}, \mathrm{e}$ \\
\hline
\end{tabular}




\section{AdAPTATION OF ENGLiSh DiPHTHONGS}

Before discussing substitution, a few remarks should be made on the nature of the diphthong. In defining the diphthong it was indicated that a diphthong is a two-part vowel sound and that these sounds should be pronounced as a single syllable. The phonetic symbols used for each diphthong represent the beginning and the end of the vowel glide. According to Crystal (1992: 105) "one element in the diphthong is always more sonorous than the other, if this is the first element the diphthong is said to be 'falling' or 'descending', if the second, it is 'rising' or 'ascending'?

He goes on to describe sonority as "the overall loudness of a sound, relative to others of the same pitch, stress and duration. Sounds are said to have an inherent sonority, which accounts for the impression of a sound carrying further" (1992:320).

Diphthongs are rare in Bemba. The English diphthongs coming into the language through loanwords all show a pattern of adaptation similar to the one exhibited by the monophthongs. In most cases, there is either vowel coalescence, or deletion of the second element of the diphthong, the resultant adapted form then being a single vowel. In the latter strategy, what is the deleted is the less prominent vowel in the combination. According to Augusto (2012), elision is a process under which a speech segment, an oral vowel in this case, undergoes zero realization. Consequently, in its strategies to avoid diphthongs, Bemba elides the less prominent vowel, generally, when the combination of vowels falls onto a less or the least prominent syllable of the word in question.

\subsection{Adaptation of /əo/}

The English diphthong /əo/ is adapted into Bemba through a process of vowel coalescence, producing the back, open mid vowel [o] in loanwords. Examples are shown below:

$\begin{array}{ll}\text { English } & \text { Bemba } \\ \text { /kəotf/ 'coach' } & \text { koci } \\ \text { /kəol/ 'coal' } & \text { koo } \\ \text { /kəot/ 'coat' } & \text { ikooti } \\ \text { /'kəubra/ 'cobra' } & \text { kobula }\end{array}$

\subsection{Adaptation of /es/}

The English diphthong /es/ is adapted in Bemba by elimination of the second element of the diphthong, leaving only [e] as the nativisized form in the language. Examples are shown below.

$\begin{array}{ll}\text { English } & \text { Bemba } \\ \text { /greId/ 'grade' } & \text { keleti } \\ \text { /greI/ 'gray' } & \text { kilee } \\ \text { /'Indikertə(r) 'indicator' } & \text { indiketa } \\ \text { /dzerl/ 'jail' } & \text { cele }\end{array}$

\subsection{Adaptation of $/ \mathbf{a} \delta /$}

$\begin{array}{ll}\text { English } & \text { Bemba } \\ \text { /blauz/ 'blouse' } & \text { bilausshi } \\ \text { /taon/ 'town' } & \text { tauni } \\ \text { /'kpmpaond/ 'compound' } & \text { kompaund }\end{array}$




\subsection{Adaptation of /ai/}

The examples of this integration are shown below.

(24)

$\begin{array}{ll}\text { English } & \text { Bemba } \\ \text { /lain/ 'line' } & \text { laini } \\ \text { /swain/ 'swine' } & \text { swaini } \\ \text { /nailnn/ nylon } & \text { nailoni } \\ \text { /fail/ 'file' } & \text { faelo } \\ \text { /stail/ 'style' } & \text { shitaelo }\end{array}$

From the examples given above the English diphthong ai is realised with the sequence of vowels /a+i/ in Bemba, where, the /a/ vowel in Bemba is a central vowel and the English /i/ is the same as that of Bemba. What this means is that diphthongs get realized as two distinct vowels belonging to two successive syllables instead of forming the nucleus of a single syllable as is the case in English.

\subsection{Adaptation of $/ \mathrm{oI} /$}

English Bemba

/boila/ 'boiler' boila

In some cases, a glide is inserted between the diphthong:

English Bemba

/boi/ 'boy' boyi

In the case of 'boy', the loanword is resyllabified by adding [i] at the end, thus forming the preferred CVCV syllable structure in the language.

\subsection{Adaptation of /ia/}

Examples:

(27)

$\begin{array}{ll}\text { English } & \text { Bemba } \\ \text { /'kæriə(r) 'çarrier', } & \text { keelya } \\ \text { /eəriə/ 'area' } & \text { elya }\end{array}$

\subsection{Adaptation of / $/ \mho ə /$}

$$
\begin{aligned}
& \text { English } \\
& \text { /mə’njuə(r)/ 'manure' manyuwa }
\end{aligned}
$$

\subsection{Adaptation of /eכ/}

$$
\begin{array}{ll}
\text { English } & \text { Bemba } \\
\text { reəlpk/ 'airlock' } & \text { eyaloko } \\
\text { reəวp:t/ 'airport' } & \text { eyapooti } \\
\text { /eə(r) } g \Lambda \mathrm{n} / \text { 'airgun' } & \text { eyakaani }
\end{array}
$$

Again here a glide is inserted between the diphthong. 


\subsection{Adaptation of /əI/}

/oI/ can either be adapted as /e/ or as /a/ as can be seen in the following examples:

a) /aI/ adapted as lel

English Bemba

/fə'sərk/ 'forsake' fuuseki

b) /aI/ adapted as /a/

English Bemba

/gər(r) 'gear' kiiya

5.10. Adaptation of /əo/

\begin{tabular}{|c|c|}
\hline English & Bemba \\
\hline /bəol/ 'bowl' & boo \\
\hline / bændzəo/ 'banjo' & banjo \\
\hline /bəu'tai/ 'bowl tie' & botai \\
\hline dzI' həひvə/ 'Jehovah' & Ceofa \\
\hline
\end{tabular}

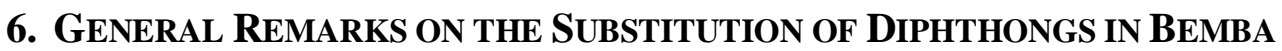

In this section, substitution of diphthongs from English has been discussed. Diphthongs from English are adjusted in various ways in Bemba. In some instances, as was shown above, diphthongs are replaced by single vowels. In some cases, a glide is inserted between the diphthongs. The problem that arises concerns the choice of the substituting vowel. From the analysis of the various diphthongs different explanations were given. In some cases the first vowel of the diphthong is chosen. If this vowel does not occur in Bemba, it is replaced by another vowel which then becomes a substitute for the diphthong. The choice of the substituting vowel seems to be determined mainly by phonetic similarity, i.e. a foreign vowel is replaced by one which is phonetically close to it. In other cases, diphthongs get realized as two distinct vowels belonging to two successive syllables instead of

\section{ADAPTATION OF ENGLISH TRIPHTHONGS}

Like diphthongs, triphthongs do not exist in Bemba. When English triphthongs are borrowed in Bemba, they are adapted is the same way as monothongs. In most cases, there is either vowel coalescence, or deletion of the second element of the diphthong, the resultant nativized form then being a single vowel. The examples below illustrate this point:

$$
\begin{array}{ll}
\text { English } & \text { Bemba } \\
\text { /avə/ 'hour' } & \text { awa } \\
\text { /ləvə/ 'lower' } & \text { loowa }
\end{array}
$$

\section{Conclusion}

The present research concludes that vowel substitution is the most appropriate repairing strategy used to preserve maximum information of English loanwords in Bemba. It is a study of vowel substitution in Bemba which concludes that the recipient language reshapes English vowels to the closest available vowels in its phonemic inventory. The paper reveals that vowel substitution is a patterned and systematic phenomenon in Bemba loanword phonology. This research also concludes that, on the basis of available vowel substitution patterns, it is possible to make predictions regarding the upcoming English words where similar substitution of vowels may be observed. 


\section{REFERENCES}

[1] Augusto, F. A. (2012). The Rephonologization of Portuguese Loanwords in Kimpombo: A Generative CV Phonology Model Account, Vol. 10, No. 9, 1547-1563 Luanda, Angola.

[2] Boen, C. P. (2014) Loan Words in Nandi From English And Kiswahili Languages. University Of Nairobi.

[3] Central Statistical Office of Zambia (2010). Census of Population and Housing. National Analytical Report. Zambia: Lusaka.

[4] Crystal, D. (1992) An Encyclopedic Dictionary of language and languages. Oxford: Blackwell.

[5] Giegerich H. J (1992). English Phonology. An introduction. Cambridge: Cambridge University Press.

[6] Hock, H. H.(1991). Principles of Historical Linguistics. New York: Mounton de Gruyter.

[7] Holden, Kyril. (1976). Assimilation rates of borrowings and phonological productivity. Language, 52, 131-147.

[8] Hussain, Q., Mahmood, R. and Mahmood A. M. (2011). Vowel Substitution: A Comparative Study of English Loans in Punjabi and Urdu. International Journal of Linguistics ISSN 19485425 2011, Vol. 3, No. 1: E31.

[9] Kangwa, N.K. (2007). A Study of English-derived Loanwords in Bemba. M.A. Dissertation. UNZA: Lusaka.

[10] Kaye, J. and Nykiel, (1979)."Loanwords and Abstract Phonotactic Constraints" The Canadian Journal of Linguistics 24:71-93.

[11] Roach, P. (1983). English phonetics and phonology. Cambridge: Cambridge University Press.

[12] Silverman, D. (1992). 'Multiple Scansions in Loanword Phonology: Evidence from Cantonese.' Phonology 9:289-328.

[13] Steinbergs, A. (1984). "Loanword Incorporation Processes: Examples from Tshiluba" Studies in the Linguistic Sciences 14(2): 115-12.

[14] Yavas, M. (1982). "Natural Phonology and Borrowing Assimilations". Linguistics 20:123-132.

\section{AUTHOR's BIOGRAPHY}

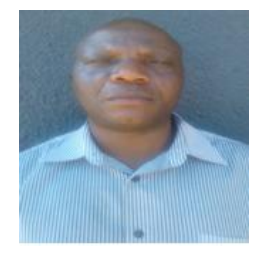

Kennedy Njenje Kangwa, is a lecturer at Kwame Nkrumah University in Zambia. He has been teaching Linguistics in African Languages since 2009. Currently, he is acting Head of Linguistics Department.

Citation: Kangwa Njenje, Kennedy. "Vowel Substitution of English Loanwords In Bemba." International Journal on Studies in English Language and Literature (IJSELL), vol 5, no. 8, 2017, pp. 30-41. doi:http://dx.doi.org/10.20431/2347-3134.0508005.

Copyright: (C) 2017 Authors. This is an open-access article distributed under the terms of the Creative Commons Attribution License, which permits unrestricted use, distribution, and reproduction in any medium, provided the original author and source are credited. 